\title{
Development of Kindergarten Child Stability Instruments
}

\author{
Lestari, L.M.E ${ }^{1^{*}}$, Antara, P.A ${ }^{2}$, Ujianti, P.R ${ }^{3}$ iD \\ 1,2,3 Universitas Pendidikan Ganesha, Singaraja, Indonesia \\ *Corresponding author: megaeni94@gmail.com
}

\section{Abstrak}

Kurangnya persiapan dan evaluasi yang dilakukan oleh dalam melaksanakan pembelajaran sehingga berakibat penurunan kualias belajar siswa. Kemampuan menstabilkan anak dengan rentang usia 4-6 tahun sangat penting karena mereka tumbuh dewasa. Penelitian ini bertujuan untuk mengembangkan instrumen asesmen kemampuan kestabilan anak Kelompok B Taman Kanak-kanak. Penelitian ini merupakan penelitian pengembangan dengan model pengembangan RDR (Research, Development, Research). Penelitian pengembangan ini menggunakan model RDR yang dikembangkan yang meliputi tiga langkah yaitu studi tentang pengembangan, pengembangan, dan efektivitas produk. Teknik pengumpulan data dalam penelitian ini adalah observasi, wawancara, dan kuesioner. Instrument yang digunakan dalam mengumpulkan data adalah kuesioner. Teknik yang digunakan untuk menganalisis data yaitu analisis kualitatif dan kuantitatif. Berdasarkan hasil analisis data, hasil uji validitas dan reliabilitas instrumen menunjukkan hasil yang sangat tinggi. Nilai uji validitas 0,92, dan uji reliabilitas 0,80. Kedua skor tersebut berada pada kategori sangat tinggi. Hal tersebut menandakan bahwa instrumen tersebut telah memenuhi kualifikasi sebagai instrumen yang bermanfaat dan layak digunakan. Implikasi penelitian ini yaitu instrument yang dikembangkan dapat digunakan sebagai pedoman dalam Menyusun penilaian belajar anak usia dini.

Kata kunci: Early Childhood, Assessment Instruments, Stability

\section{Abstract}

Lack of preparation and evaluation carried out by carrying out learning results in a decrease in the quality of student learning. The ability to stabilize children in the age range of 4-6 years is very important as they grow up. This study aims to develop an instrument for assessing the stability ability of children in Group B Kindergarten. This research is a development research with the RDR (Research, Development, Research) development model. This development research uses the developed RDR model, which includes three steps: product development, development, and effectiveness. Data collection techniques in this study were observation, interviews, and questionnaires. The instrument used in collecting data is a questionnaire. The technique used to analyze the data is qualitative and quantitative analysis. Based on the results of data analysis, the results of the validity and reliability of the instrument showed very high results. The value of the validity test is 0.92 , and the reliability test is 0.80 . Both scores are in the very high category. It indicates that the instrument has met the qualifications as a useful and appropriate instrument to use. This research implies that the instrument developed can be used as a guide in preparing early childhood learning assessments.

Keywords: Early Childhood, Assessment Instruments, Stability

$\begin{array}{ll}\text { History: } & \text { Publisher: Undiksha Press } \\ \text { Received : December 25, } 2020 & \text { Licensed: This work is licensed under } \\ \text { Revised : January 29, } 2021 & \text { a Creative Commons Attribution 3.0 License } \\ \text { Accepted : February 10, } 2021 & \text { Published : April 25, 2021 }\end{array}$

\section{Introduction}

Early childhood development occurs very quickly, and children experience significant changes with age (Khasanah \& Fauziah, 2021; Wulandari \& Suparno, 2020). Children who are guided properly will affect the development of children so that children experience changes that help them become better. Lestariani, Mahadewi, \& Antara (2019) states that growth and development at an early age require a lot of stimulation that helps children move a lot to allow for physical and psychological development. Early childhood development is influenced by several factors, including anatomical and psychological factors (Izza, 2020; Wulandari \& Purwanta, 2021). In anatomical elements, child development is seen in changes in bone structure, body piercing, and other body parts. While on psychological factors, child development is seen in motor development, both gross motor and fine motor. Children's motor development occurs when children can perform activities such as walking, jumping, 
running, kicking, and doing other movements. Early childhood development must be properly guided, one of which is through formal education. Early childhood education or PAUD in Kindergarten is a formal education that can be used as a foundation for children before obtaining further education and developing in a better direction (Dista, 2020; Marwiyati \& Istiningsih, 2021). Child development allows children to learn continuously by doing social interactions, adjusting to comfort while learning, comfort in other things and learning from simple things in the development process (Cahyaningrum, Sudaryanti, \& Purwanto, 2017; Wulandari \& Purwanta, 2021). So that teachers must create a comfortable and pleasant learning atmosphere so that the learning process can run well.

However, the problem that occurs today is the lack of preparation and evaluation carried out by students in carrying out learning, resulting in a decrease in the quality of student learning (Ayuni et al, 2021; Shaleh \& Anhusadar, 2021). This problem also occurs in one of the kindergartens. Based on observations made on group B children at the TK Wisata Kumara Timur, the teacher faced several obstacles during the learning process. The problem faced by teachers at the TK Wisata Kumara Timur is that the implementation of learning that aims to improve the stability of the child's body has not run optimally. The teacher's error during the learning process is the lack of preparation and evaluation in carrying out learning, resulting in decreased quality of education (Darmadi, 2015; Utami \& Hasanah, 2019). The problems faced making teachers unable to provide maximum value to children during the learning process. Teacher errors in giving grades are influenced by several procedures that must be carried out to determine student development so that no results are obtained following the child's development (Fadlilah, 2020; Oktarina \& Fatonah, 2021; Rahayu, 2020). Teacher assessment in learning is still based on student work or portfolios. The reference used results in an evaluation that has not been maximized following the student's abilities (Hidayat \& Andriani, 2020; Sari \& Setiawan, 2012). Another problem faced during direct observation is the lack of teacher creativity in developing learning activities. It has an impact on learning activities that seem monotonous because of the repetition made by the teacher. Boring learning makes children less motivated to take part in learning. Therefore, the need for references can be used as a guideline to assess the balance of children's abilities to suit the learning objectives.

A definite reference is needed based on the problems faced, which plays an important role in determining the objective assessment criteria. The difficulties encountered can be overcome by designing assessment instruments related to the child's body balance ability to get accurate results and follow the child's motor development, especially related to the child's body balance, such as the child's static and dynamic stability. The assessment instrument designed must meet the requirements as a valid and reliable assessment instrument. The instrument for assessing the body balance of group B children at the Kumara Timur Tourism Kindergarten is very good and reliable. So we need an instrument that can be used as a reference in the assessment of early childhood students. The development of the instrument aims to assist teachers in determining the standards and suitability of the assessment based on the assessment indicators (Hulukati \& Rahmi, 2020; Sari \& Setiawan, 2012). Appropriate evaluation can be used to measure the ability of students' body balance in learning. Preparation is done before learning occurs by planning activities that can stimulate the child's body balance ability. At the same time, evaluation is carried out during education by looking at what happens during learning (Agustin et al, 2021; Ayuni et al., 2021). If the evaluation is appropriate, it can measure the success of the learning objectives.

The purpose of early childhood education is the physical or motor aspect of children, which aims to regulate movement or body skills, both finely and grossly (Astuti \& Istiarini, 2020; Shaleh \& Anhusadar, 2021). The emotional element is the child's ability to control himself and develop a positive attitude, moral or religious aspects that understand the rules in 
spiritual values. The social element in question is that children can socialize and can accept the differences that exist in society, aspects of language that children can communicate and use spoken language in everyday life, and aspects of art and creativity related to the ability and sensitivity to rhythm to express it (Izza, 2020; Perdina, Safrina, \& Sumadi, 2019; Sari, Hartati, \& Yetti, 2019). Stimulating all aspects of development at an early age is very important to help further development of children. The development in question is physical development during the child's growth and development and psychological development, as previously mentioned (Mardliyah, Yulianingsih, \& Putri, 2021; Pebriana, 2017). The importance of early childhood development, educational facilities are a place for children to develop. So it is important to develop motor skills in early childhood. Motor development means that changes in children are influenced by several factors, such as maturity and experience gained in everyday life. These factors play an active role in the growth and development of children, especially early childhood mentioned, early age is the golden age for children to grow and develop (Cllaudia, Widiastuti, \& Kurniawan, 2018; Suriati et al, 2020).

Children who have good motor development indicate that the child is in good and healthy condition. Through motor activities, children can release restrained emotions by making movements to feel comfortable (Tanto \& Sufyana, 2020; Wandi \& Mayar, 2020). Children who have fine motor development can carry out daily activities independently and increase self-confidence. Through fine motor development, children can socialize well through their movements. Children will feel comfortable psychologically if their motor development is fine. In addition, gross motor skills are carried out by coordinating the body's muscles, such as the leg and hand muscles, and the child's whole body (Darmiatun \& Mayar, 2020; Ulfah, Dimyati, \& Putra, 2021). Therefore, in carrying out gross motor movements, balance is needed in the child's body. Balance means coordination to react to changes that occur in a controlled manner. This study aims to develop an instrument for assessing the stability ability of children in Group B of the Taman Kanak-Kanak Wisata Kumara Timur. It is hoped that the developed instrument can be an instrument that can assess the motor skills of early childhood students. And become a guide in early childhood assessment.

\section{Methods}

This research was a type of research using the RDR (Research, Development, Research) development model. Research with the RDR model developed by Borg and Gall (Sugiyono, 2016). Development research was carried out in three steps: product development, development, and effectiveness. The development of an instrument aimed to assess an instrument meets the standard as a good instrument. The subjects in this study were group B students at the TK Wisata Kumara Timur. This research variable was an instrument for assessing children's body balance ability in group B TK Wisata Kumara Timur. The first stage of research was a preliminary study or research. It was done following the research model applied in this study. Preliminary studies were conducted to obtain incomplete valuable data as a source of information for the next stage. This step was carried out by observing and interviewing group B teachers and the TK Wisata Kumara Timur Head. Observations and interviews were also useful as information related to the description of the situation and condition of the TK Wisata Kumara Timur.

The second stage was the development stage. At this stage, the planning and design of instruments that assess the child's balance ability were carried out according to the situation and field conditions. At the development stage, the preparation of a questionnaire was also developed used in the questionnaire. The instrument designed in this study consisted of 14 statement items. The idea developed comes from 2 dimensions of body balance: static stability and dynamic stability. The statement of static stability was redeveloped into four 
indicator items, and the idea of dynamic balance was developed into three indicator points. The development of statement items on the assessment instrument was developed based on predetermined indicators. Each indicator for dynamic balance and static balance was divided into two return statements. The statement of the assessment instrument provides information to respondents about the assessment reference used to assess the stability of the child's body in the learning process. Indicators of static balance include standing with legs and arms outstretched for 10 seconds, standing on one leg with both hands on the waist, standing with one leg folded in front of the chest, and standing on one leg with the right arm straight up with the body leaning forward. While indicators of dynamic balance are walking with objects overhead, jumping on one leg, and walking along a line.

It is necessary to use a scale to make it easier for respondents to assess based on the experience seen in the learning process. The score setting on the questionnaire is designed using a Likert scale as follows, a score of 4 for highly developed answers (BSB), a score of 3 for answers that develop as expected (BSH), a score of 2 for solutions that have begun to be created or (MB), and a score of 1 for answers that have not developed (BB). The Likert scale aimed to make it easier for respondents to choose answers according to the statements listed in the questionnaire. The last stage is to test the effectiveness of the product. Product effectiveness tests were carried out by experts or experts who have competence in their fields. Product testing aimed to test the effectiveness and efficiency of the products that have been made. In this study, the data that had been obtained tested for validity and reliability. As the main requirement to produce a quality product, the instrument developed must have good validity and reliability. In this third stage, experts respond following predetermined criteria related to the topic so that the resulting product was high quality.

\section{Results and Discussion}

The results showed that the instrument developed was included in the criteria of the instrument with a very high level of validity and reliability. The validity of a tool determines the function of a measuring instrument following its measurement objectives. It means that the reduction reflects the seriousness of something being measured. The validity test results showed the results of 0.92 , which were calculated using the Gregory formula. These results were obtained from statements that are said to be relevant and irrelevant by experts. From the two dimensions, namely static balance, and dynamic balance, 14 statements related to the balance of the child's body were obtained. Of the fourteen items of the questionnaire statement, there was one irrelevant item. The first expert stated that all statement points on the questionnaire were relevant and followed its purpose. However, the second expert revealed that the third item on the questionnaire was irrelevant. The questionnaire item developed from an indicator of standing on one leg with both hands on the waist. While the statement in the questionnaire is "Stand up using the right leg as a support, with the left arm straight up with the body leaning forward". After passed the validity test, the instrument for assessing the child's balance ability is continued to the reliability test stage to produce an accurate instrument. The reliability test was carried out with Microsoft Excel 2010. In the reliability test, all statement items were assessed to obtain accurate results. Recapitulation of reliability test results can be seen in the Table 1 .

Based on Table 1, it can be stated that the statement items listed on the child's balance ability assessment instrument are 14 points. The results of the calculations carried out stated that the results of the instrument reliability test were 0.80 . The final score indicated that the instrument developed was in very high category. The standard deviation score in the reliability test of the instrument for assessing the balance ability of children in Group B of the TK Wisata Kumara Timur is 2 . Based on the reliability test results, it can be stated that the instrument that had been developed had high accuracy. In addition, high reliability indicates 
that an instrument was suitable for measuring learning related to body balance. Based on the validity and reliability tests presented, the instrument developed had a measurement accuracy following the research objectives. With a statement that had been declared relevant as many as 13 statement items, the validity test of the instrument for assessing the body balance ability of group B children at the TK Wisata Kumara Timur was included in very high validity. Instruments with very high validity mean that they can function as good and precise measuring instruments.

Table 1. Instrument Reliability Test Results

\begin{tabular}{cccc}
\hline $\begin{array}{c}\text { Statement Item } \\
\text { Number }\end{array}$ & $\mathbf{1}$ & Experts & \multirow{2}{*}{ Number of Scores } \\
\cline { 2 - 3 } $\mathbf{p q}$ & & $\mathbf{2}$ & 0,5 \\
$\mathbf{N}$ & 14 \\
$\mathbf{S t}^{2}$ & & 2 \\
$\mathbf{r}^{\mathbf{1 1}}$ & & 0,80 & \\
\hline
\end{tabular}

Description:

$\mathrm{Pq}:$ the proportion of answers from the summation result of $\mathrm{p}+\mathrm{q}$

$\mathrm{N} \quad$ : many items

$\mathrm{St}^{2} \quad$ : standard deviation of the total score

$\mathrm{r}^{11}$ : reliability test device

The validity test results also confirmed that each item of the assessment instrument statement follows the topic raised in this study. A separate validity test was a test of the content contained in an instrument. So, every statement must had a purpose or an element in it. The representation in the assessment instrument was a reference that will be used in assessing a child's balance ability. Therefore, the validity test results show that the content or content in it is good and already represents the topic studied about the balance of the child's body. It can be concluded that the developed instrument was suitable for use by teachers to assess early childhood motor skills. Several factors caused this. First, the instrument developed was suitable for teachers to assess early childhood motor skills because it followed the abilities of early childhood. The designed instrument had also gone through the trial phase and produced the correct and the same results following the main requirements of a proper and good instrument. A good and appropriate instrument can be used to measure (Gaol, Khumaedi, \& Masrukan, 2017; Sutijan et al, 2015). Each item in the developed instrument proves that the instrument can be used as a reliable measuring tool that can produce an assessment following the criteria for assessing children's balance and dynamic and static body balance.

Second, the instrument developed was suitable for assessing early childhood motor skills because it followed early childhood development. Children's physical or motor development is very important because it relates to their body movement and physical condition (Tanto \& Sufyana, 2020; Wandi \& Mayar, 2020). Children's physical or motor skills are divided into gross motor skills, fine motor skills, and occupational health and safety behaviors. The instrument developed met the criteria in assessing children's motor skills so that this instrument was feasible to be applied. The quality of the products developed in this study was very good. The instruments developed are following early childhood development (Solihah, Jubaedah, \& Rifa, 2020). The instrument developed is feasible to apply because the points in each statement developed are interrelated so that the assessment model developed can assess character education in PAUD (Iswantiningtyas \& Wulansari, 2018). The same results indicate that the instrument developed can be used according to its function to measure the balance ability of children in Group B of the TK Wisata Kumara Timur. This 
research implies that the instrument developed can guide developing other instruments related to motor assessment in early childhood. The instruments developed can be used by teachers in assessing motor skills in early childhood.

\section{Conclusion}

Based on the results of data analysis, the development of the instrument for assessing the ability of the body balance of Group B children conducted at the TK Wisata Kumara Timur was declared to have very high validity and reliability. It can be concluded that teachers can use the instrument for assessing children's body balance abilities.

\section{References}

Agustin, M., Inten, D. N., Permatasari, A. N., \& Mulyani, E. (2021). Strategi Guru PAUD dalam Mengembangkan Kecerdasan Interpersonal Anak Usia Dini di Saat Belajar dari Rumah. Jurnal Obsesi: Jurnal Pendidikan Anak Usia Dini, 5(2). https://doi.org/https://doi.org/10.31004/obsesi.v5i2.1055.

Astuti, R. F., \& Istiarini, R. (2020). Upaya Meningkatkan Kemampuan Membaca Permulaan Anak Usia 5-6 Tahun Melalui Media Puzzle di PAUD Flamboyan Sukasari Kota Tangerang. Ceria: Jurnal Program Studi Pendidikan Anak Usia Dini, 8(2). https://doi.org/http://dx.doi.org/10.31000/ceria.v11i2.2338.

Ayuni, D., Marini, T., Fauziddin, M., \& Pahrul, Y. (2021). Kesiapan Guru TK Menghadapi Pembelajaran Daring Masa Pandemi Covid-19. Jurnal Obsesi : Jurnal Pendidikan Anak Usia Dini, 5(1). https://doi.org/https://doi.org/10.31004/obsesi.v5i1.579.

Cahyaningrum, E. S., Sudaryanti, S., \& Purwanto, N. A. (2017). Pengembangan Nilai-Nilai Karakter Anak Usia Dini Melalui Pembiasaan Dan Keteladanan. Jurnal Pendidikan Anak, 6(2), 203-213. https://doi.org/10.21831/jpa.v6i2.17707.

Cllaudia, E. S., Widiastuti, A. A., \& Kurniawan, M. (2018). Origami Game for Improving Fine Motor Skills for Children 4-5 Years Old in Gang Buaya Village in Salatiga. Jurnal Obsesi: Jurnal Pendidikan Anak Usia Dini, 2(2). https://doi.org/https://doi.org/10.31004/obsesi.v2i2.97.

Darmadi, H. (2015). Tugas, Peran,Kompetensi, dan Tanggung Jawab Menjadi Guru Profesional. Jurnal Edukasi, https://doi.org/http://dx.doi.org/10.31571/edukasi.v13i2.113.

Darmiatun, S., \& Mayar, F. (2020). Meningkatkan Kemampuan Motorik Halus Anak melalui Kolase dengan Menggunakan Bahan Bekas pada Anak Usia Dini. Jurnal Obsesi: Jurnal Pendidikan Anak Usia Dini, https://doi.org/https://doi.org/10.31004/obsesi.v4i1.327.

Dista. (2020). Manajemen Pendirian Taman Kanak-Kanak (Studi Kasus Di TK Fastrack Funschool Yogyakarta). Jurnal Pendidikan Anak Usia Dini Undiksha, 8(2), 101-111. https://doi.org/http://dx.doi.org/10.23887/paud.v8i2.22582.

Fadlilah, A. N. (2020). Strategi Menghidupkan Motivasi Belajar Anak Usia Dini Selama Pandemi COVID-19 melalui Publikasi. Jurnal Obsesi : Jurnal Pendidikan Anak Usia Dini, 5(1), 373. https://doi.org/10.31004/obsesi.v5i1.548.

Gaol, P. L., Khumaedi, M., \& Masrukan, M. (2017). Pengembangan Instrumen Penilaian Karakter Percaya Diri pada Mata Pelajaran Matematika Sekolah Menengah Pertama. Journal of Research and Educational Research Evaluation, 6(1). https://doi.org/https://doi.org/10.15294/jrer.v6i1.16209.

Hidayat, W., \& Andriani, A. (2020). Pelaksanaan Penilaian Autentik Guru Pendidikan Anak Usia Dini. Cakrawala Dini: Jurnal Pendidikan Anak Usia Dini, 12(2). https://doi.org/https://doi.org/10.17509/cd.v11i2.24922. 
Hulukati, W., \& Rahmi, M. (2020). Instrumen Evaluasi Karakter Mahasiswa Program Pendidikan Guru Pendidikan Anak Usia Dini. Jurnal Obsesi : Jurnal Pendidikan Anak Usia Dini, 4(2). https://doi.org/https://doi.org/10.31004/obsesi.v4i2.468.

Iswantiningtyas, V., \& Wulansari, W. (2018). Pengembangan model penilaian pendidikan karakter anak usia dini. Jurnal Pendidikan Usia Dini, 12(2). https://doi.org/https://doi.org/10.21009/jpud.122.17.

Izza, H. (2020). Meningkatkan Perkembangan Sosial Anak Usia Dini melalui Metode Proyek. Jurnal Obsesi: Jurnal Pendidikan Anak Usia Dini, 4(2). https://doi.org/https://doi.org/10.31004/obsesi.v4i2.483.

Khasanah, B. L., \& Fauziah, P. (2021). Pola Asuh Ayah dalam Perilaku Prososial Anak Usia Dini. Jurnal Obsesi: Jurnal Pendidikan Anak Usia Dini, 5(2). https://doi.org/https://doi.org/10.31004/obsesi.v5i1.627.

Lestariani, L. P., Mahadewi, L. P. P., \& Antara, P. A. (2019). Pengaruh model pembelajaran tari kreatif terhadap kemampuan motorik kasar kelompok b gugus I Kecamatan Banjar. Jurnal Pendidikan Anak Usia Dini Undiksha, 7(3), 236-245. https://doi.org/https://doi.org/10.23887/paud.v7i2.19010.

Mardliyah, S., Yulianingsih, W., \& Putri, L. S. R. (2021). Sekolah Keluarga: Menciptakan Lingkungan Sosial untuk Membangun Empati dan Kreativitas Anak Usia Dini. Jurnal Obsesi: Jurnal Pendidikan Anak Usia Dini, 5(1). https://doi.org/https://doi.org/10.31004/obsesi.v5i1.665.

Marwiyati, S., \& Istiningsih, I. (2021). Pembelajaran Saintifik pada Anak Usia Dini dalam Pengembangan Kreativitas di Taman Kanak-Kanak. Jurnal Obsesi: Jurnal Pendidikan Anak Usia Dini, https://doi.org/https://doi.org/10.31004/obsesi.v5i1.508.

Oktarina, A., \& Fatonah, S. (2021). Pengamatan Tentang Pembelajaran Dan Penilaian Pada Anak Usia Dini Di Era Pandemi Covid-19. Cakrawala Dini: Jurnal Pendidikan Anak Usia Dini, 12(1). https://doi.org/https://doi.org/10.17509/cd.v12i1.30278.

Pebriana, P. H. (2017). Analisis Penggunaan Gadget Terhadap Kemampuan Interaksi Sosial Anak Usia Dini. Jurnal Obsesi: Journal of Early Childhood Education, 1(1). https://doi.org/https://doi.org/10.31004/obsesi.v1i1.26.

Perdina, S., Safrina, R., \& Sumadi, T. (2019). Peningkatan Kemampuan Sosial melalui Bermain Kartu Estafet pada Anak Usia Dini. Jurnal Obsesi : Jurnal Pendidikan Anak Usia Dini, 3(2). https://doi.org/https://doi.org/10.31004/obsesi.v3i2.222.

Rahayu, N. (2020). Hasil Karya Siswa Sebagai Penilaian Autentik Berbasis Kelas Di Kelompok B Usia 5-6 Tahun Tk An-Nur 1 Yogyakarta. Cakrawala Dini: Jurnal Pendidikan Anak Usia Dini, https://doi.org/https://doi.org/10.17509/cd.v11i1.17279.

Sari, C. R., Hartati, S., \& Yetti, E. (2019). Peningkatan Perilaku Sosial Anak melalui Permainan Tradisional Sumatera Barat. Jurnal Obsesi : Jurnal Pendidikan Anak Usia Dini, 3(2). https://doi.org/https://doi.org/10.31004/obsesi.v3i2.225.

Sari, K. M., \& Setiawan, H. (2012). Kompetensi Pedagogik Guru dalam Melaksanakan Penilaian Pembelajaran Anak Usia Dini. Jurnal Obsesi: Jurnal Pendidikan Anak Usia Dini, 4(2). https://doi.org/https://doi.org/10.31004/obsesi.v4i2.478.

Shaleh, M., \& Anhusadar, L. (2021). Kesiapan Lembaga PAUD dalam Pembelajaran Tatap Muka pada New Normal. Jurnal Obsesi: Jurnal Pendidikan Anak Usia Dini, 5(2). https://doi.org/https://doi.org/10.31004/obsesi.v5i2.1139.

Solihah, A. N., Jubaedah, Y., \& Rifa'i, M. S. S. (2020). Pengembangan Instrumen Pengukuran Perkembangan Sosial-Emosional Anak Berbasis Home-Based Childcare. Widyadari, 6(1). https://doi.org/https://doi.org/10.5281/zenodo.3517997.

Sugiyono. (2016). Metodologi Pendidikan. Bandung: Alfabeta. 
Suriati, Kuraedah, Erdiyanti, \& Anhusadar, L. O. (2020). Meningkatkan Keterampilan Motorik Halus Anak melalui Mencetak dengan Pelepah Pisang. Jurnal Obsesi: Jurnal Pendidikan Anak Usia Dini, 4(1). https://doi.org/10.31004/obsesi.v4i1.299.

Sutijan, S., Makhfud, H., Lestari, L., \& Chumdari, C. (2015). Pengembangan Instrumen Penilaian Pendidikan Karakter Terpadu. Paedagogia, 18(2). Retrieved from https://jurnal.fkip.uns.ac.id/index.php/paedagogia/article/view/7517/0.

Tanto, O. D., \& Sufyana, A. H. (2020). Stimulasi Perkembangan Motorik Halus Anak Usia Dini dalam Seni Tradisional Tatah Sungging. Jurnal Obsesi : Jurnal Pendidikan Anak Usia Dini, 4(2). https://doi.org/https://doi.org/10.31004/obsesi.v4i2.421.

Ulfah, A. A., Dimyati, D., \& Putra, A. J. A. (2021). Analisis Penerapan Senam Irama dalam Meningkatkan Kemampuan Motorik Kasar Anak Usia Dini. Jurnal Obsesi : Jurnal Pendidikan Anak Usia Dini, https://doi.org/https://doi.org/10.31004/obsesi.v5i2.993.

Utami, \& Hasanah. (2019). Kompetensi Profesional Guru Dalam Penerapan Pembelajaran Tematik Di SD Negeri Maguwoharjo 1 Yogyakarta. Pionir Jurnal Pendidikan, 8(2). https://doi.org/http://dx.doi.org/10.22373/pjp.v8i2.6232.

Wandi, Z. N., \& Mayar, F. (2020). Analisis Kemampuan Motorik Halus dan Kreativitas pada Anak Usia Dini melalui Kegiatan Kolase. Jurnal Obsesi : Jurnal Pendidikan Anak Usia Dini, 4(1). https://doi.org/https://doi.org/10.31004/obsesi.v4i1.347.

Wulandari, A., \& Suparno, S. (2020). Pengaruh Model Problem Based Learning terhadap Kemampuan Karakter Kerjasama Anak Usia Dini. Jurnal Obsesi : Jurnal Pendidikan Anak Usia Dini, 4(2). https://doi.org/https://doi.org/10.31004/obsesi.v4i2.448.

Wulandari, H., \& Purwanta, E. (2021). Pencapaian Perkembangan Anak Usia Dini di Taman Kanak-kanak selama Pembelajaran Daring di Masa Pandemi Covid-19. Jurnal Obsesi : Jurnal Pendidikan Anak Usia Dini, 5(1). https://doi.org/https://doi.org/10.31004/obsesi.v5i1.626. 